\title{
PEMETAAN WILAYAH BANK SAMPAH GUNA MENUNJANG PENERAPAN GREEN CONSTITUTION DI KOTA MANADO
}

\author{
Felly Ferol Warouw ${ }^{1}$, Fransiscus Jani Lumape ${ }^{2}$, Piet Hein Pusung ${ }^{2}$, Herwyn Jefler Malonda ${ }^{3}$ \\ ${ }^{1}$ Program Studi Arsitektur, Fakultas Teknik, Universitas Negeri Manado \\ ${ }^{2,3}$ Manajemen Pemerintahan, Institut Pemerintahan Dalam Negeri \\ ${ }^{4}$ Program Studi Ilmu Lingkungan, Universitas Brawijaya Malang \\ e-mail: ferolwarouw@unima.ac.id
}

\begin{abstract}
The global issue of waste is very worrying because it has a direct impact on the biotic and abiotic environment and has even led to non-natural disasters. Reducing waste from its source by sorting and further managing it into new products is a way to deal with waste problems. Reducing waste from its source by sorting it and saving it at the Waste Bank is a promising breakthrough that can encourage people to actively participate in waste management while supporting the implementation of a green constitution in the future. The purpose of this research is to obtain a mapping of the distribution area of waste banks in Manado City to support the implementation of the green constitution. Data obtained through research using a mapping application and conducted with the google search engine, on the basis that this application is widely used in finding addresses by various users. The data were analyzed regarding the mapping of the position of waste banks in Indonesia, found on the website of the ministry of environment and forestry under the name of the national waste bank management information system. However, when it was focused on finding a special waste bank in the city of Manado, the smash application could show the location of existing waste banks. The results of further research indicate a mapping of the position of waste banks in the city of Manado, consisting of the center, the outskirts, and outside the city. Furthermore, the results of the comparison of the three waste banks resulted in a management method which concluded that effective waste bank management was carried out through a strategy of implementing $3 R$ (Reuse, Reduce, Recycle) in waste management at the source at the community level. The results of the mapping are expected to become the basis for developing a green constitution policy as a development model for waste bank management in the future.
\end{abstract}

Keywords: Mapping, Waste Bank Management, Green Constitution, Manado City

\begin{abstract}
Abstrak: Isu global sampah sangat mengkhawatirkan karena berdampak langsung pada lingkungan biotik dan abiotik bahkan telah menyebabkan bencana non alam. Mengurangi sampah dari sumbernya dengan metode pemilahan dan dikelola lanjut menjadi produk baru merupakan cara untuk menangani permasalahan sampah. Mengurangi sampah dari sumbernya dengan pemilahan selanjutnya ditabung di Bank Sampah adalah terobosan yang menjanjikan dan dapat mendorong masyarakat untuk berpartisipasi aktif dalam pengelolaan sampah sekaligus menunjang penerapan green constitution di masa yang akan datang. Tujuan penelitian ini untuk mendapatkan pemetaan wilayah persebaran bank sampah di Kota Manado dalam menunjang penerapan green constitution. Data diperoleh melalui penelitian menggunakan aplikasi pemetaan dan dilakukan dengan mesin pencari google, dengan dasar bahwa aplikasi ini banyak digunakan dalam mencari alamat oleh berbagai pengguna. Data dianalisis menyangkut pemetaan posisi bank sampah yang ada di Indonesia, ditemukan dalam situs milik kementerian lingkungan hidup dan kehutanan dengan nama sistem informasi pengelolaan bank sampah nasional. Namun saat difokuskan pencarian bank sampah khusus di kota Manado, maka aplikasi smash yang dapat menunjukkan lokasi bank sampah yang ada. Hasil penelitian selanjutnya menunjukkan pemetaan posisi bank sampah di kota Manado terdiri dari pusat, pinggiran, dan luar kota. Selanjutnya hasil perbandingan ketiga bank sampah menghasilkan metode pengelolaan yang dapat disimpulkan bahwa pengelolaan bank sampah efektif dilakukan melalui strategi penerapan 3R (Reuse, Reduce, Recycle) dalam pengelolaan sampah pada sumbernya di tingkat masyarakat. Hasil pemetaan diharapkan menjadi dasar pengembangan kebijakan green constitution sebagai pengembangan model pengelolaan bank sampah di masa yang akan datang.
\end{abstract}

Kata Kunci: Pemetaan, Pengelolaan Bank Sampah, Green Constitution, Kota Manado 